\title{
The Convergence of Organizational Culture, Structure and Human Capital Performance: A Conceptual Analysis
}

\author{
Williams Kwasi Peprah \\ School of Business, \\ Valley View University, Oyibi, Accra - Ghana. \\ Josephine Ganu \\ School of Postgraduate Studies, \\ Adventist University of Africa, Nairobi, Kenya.
}

\begin{abstract}
There is no doubt that talented employees are the backbone of every organizational success. An organization can have an advantage over its competitors by using better technology, lower costs, more innovative products, etc. However, these advantages do not just happen by themselves; it takes talents within the organization to create, implement and sustain competitive advantages. Thus, the long-term success of any organization ultimately depends on maximizing the effectiveness of employees in accomplishing organizational goals. The key to the desired results is creating a favorable context within which employees must operate. Hence, organizational structure and culture are key to employees' effectiveness. Therefore, using literature review method, this conceptual paper examined the roles of organizational culture and organizational structure in maximizing human capital performance. Further, this article recommends research propositions based on a framework for empirical examination of the relationships and impact of organizational culture and structure on human capital performance and sustainable competitive advantage.
\end{abstract}

Keywords: Organizational Culture, Organizational Structure, Human Capital, competitive advantage, performance

\section{INTRODUCTION}

There is no doubt that talented employees are the backbone of every organizational success. An organization can have an advantage over its competitors by using better technology, lower costs, more innovative products, etc. However, these advantages do not just happen by themselves; it takes talents within the organization to create, implement and sustain competitive advantages. Thus, the long-term success of any organization ultimately depends on maximizing the effectiveness of employees in accomplishing organizational goals. The key to the desired results is creating a favorable context within which employees must operate. Hence, organizational structure and culture are key to employees' effectiveness. These have significant impact on how employees communicate and cooperate with each other, as well as how they view their work environment. As indicated by Jeston and Neils (2014), organizational efficiency and effectiveness depend on employees who are the functionaries of culture and structure.

Culture is created by people and structure is created for people which makes organization people-centered (Newman, 2012). In the view of Hakim (2015), an organization is a container of activities and processes where people interact. Getting the right fit of employees will cause the needed outcome for organizations who have a winning culture and structure. 
We know the importance of culture and structure organization, but we hardly look at them as effective strategies to human capital performance. Few papers (e.g. Mosley, 2007) have discussed organization structure and corporate culture together. This article is an attempt to conceptually explore and demonstrate through a proposed conceptual model how organization structure and corporate culture relate to one another and the role they play in maximizing human capital. We therefore argue that by effectively organizing people and setting boundaries through culture, talents would be maximized to facilitate sustainable organizational performance. The paper therefore highlights the review of literature on the concept of human capita, corporate culture and structure; and presents a conceptual framework along with research propositions.

\section{The Concept of Human Capital Resources}

The concept of human capital dates back to the era of Adam Smith. In defining capital Smith (1776) included human capital by stating that acquisition of talents, education, study or apprenticeship cost is a person's capital. The term was popularized in the $18^{\text {th }}$ century by Irving Fisher, when he explained that the concept of capital should include "the bodies of human beings and theirs mind too (Kolomiiets and Petrushenko, 2017). The Organization for Economic Co-operation and Development (OECD) defines human capital as the "knowledge, skills, competencies and attributes embodied in individuals that facilitate the creation of personal, social and economic wellbeing"' (Keeley, 2007, p. 29). Keeley asserts that education is a key factor in forming human capital which is reflected across a range of economic and social areas including organizations. Therefore, Keeley simply describes human capital as- the quality of the workforce. For Bontis, Dragonetti, Jacobsen and Roos (1999), human capital represents the human factor in the organization which is the combined intelligence, skills and expertise that gives the organization its distinctive character. The human elements of an organization are those that are capable of learning, changing, innovating and providing the creative thrust which if properly managed can ensure the long-term survival of the organization (cited in Amstrong, p.67). For Scarborough and Elias (2002), human capital is non-standardized, tacit, dynamic, context dependent and unique in people. Such capital cannot be imitated or copied. Goldin's (2014) views human capital as a stock of talent, health, and expertise of an employee. However, Baron (2011) argues that human capital is not only about the knowledge, skills and experience of individuals; it extends to their commitment and willingness to share their knowledge, skills, experience to add value to the organization. For the interest of the paper, human capital refers to employees' knowledge and skills accumulated through experience.

Therefore, in order for organizations to achieve high performance through sustainable competitive advantage, they must recognize employees as the critical key to success and invest in their human capital. As noted by Hitt (2002), human capital importance is the unique resources of any organization which generates higher income, life satisfaction, social cohesion and competitive advantage. The added value that people can contribute to an organization is emphasized by human capital theory. It regards people as assets and stresses that investment by organizations in people will generate worthwhile returns.

\section{Underlying Theories of Human Capital Resources}

Human capital theory is associated with the resource-based view(RBV) of the firm developed by Barney (1991). This proposes that sustainable competitive advantage is attained when the firm has valuable human resource pool that cannot be imitated or substituted by rivals. The RBV is premised on the assumption that competitive advantage does not stem from market and industry structures; rather, it is derived from a firm's internal resources. These resources are simultaneously valuable, rare, imitable and non-substitutable (VRIN). In other others, VRIN 
resource is a definite source of sustainable competitive advantage. What is most likely to create an advantage is how these resources are utilized and not only if the resources are possessed. According to Ambrosini and Thomas (2016), "one consequence of this recognition that intangible resources are the most likely sources of competitive advantage is the acknowledgement that people matter" (p. 186).

However, to fully exploit the VRIN resource, Barney and Hesterly (2006) caution that certain organizational components such as structure and control systems must be in place. Thus, by implication, the value of a VRIN resource is contingent on other factors such as organizational structure and culture. An organization's culture is for instance inimitable. As organizations grow, they develop traditions and norms which makes them unique and distinct. Such traditions and norms can be extremely difficult to imitate because they exist due to the organization's unique context, history and way of doing things. Ambrosini and Thomas (2016) note that in order for organizations to manage their VRIN resources effectively, they require three kinds of efforts: they must protect current resources, continually improve their resources and build new resources to ensure that changes in the environment do not render current resources obsolete.

\section{The Power of Organizational Culture on Employees}

Employees come in different shapes and sizes, abilities and skills, ages, gender, educational background and many more. However, what most of these employees have in common is a collective need to make useful contributions to those around them. Culture sets the limits on what is considered acceptable and unacceptable behaviors and influences employees' thoughts and expectations. It compels employees into accepting and following normative behavior prescribed by their organizations. It is the social energy that drives the organization to success or failure (Hitt, Ireland and Hoskisson, 2015).

It is very difficult to have a single definition for culture (Alisa \& Senija, 2010) and by extension organizational culture. Though organizational culture has been defined in several ways and dimensions, in this paper, we adopted the definition by Colquitt, Lepine \& Wesson (2013) who describe organizational culture as the "shared social knowledge within an organization regarding the rules, norms, and values that shape the attitudes and behavior of its employees" (p. 518). This system of shared meaning creates common understanding among organizational members about what is appropriate and acceptable behavior, thereby creating an institutionalized standard of how the organization functions. Corporate culture is an important VRIN resource when employees are tightly connected through the culture. More so, corporate cultures that place high value on innovativeness and risk-taking for instance, encourage employees to think beyond their current knowledge and skills and explore their potential capabilities. Such cultures perceive failure as part of organizational learning and growth which is crucial for enhancing human capital (Bateman and Snell (2013).

Organizational culture is generally classified into three levels- artifacts, espoused beliefs and values, and basic underlying assumptions (Schein, 2010; Colquitt; Lepine \& Wesson, 2013). According to Schein (2010), the artefacts of culture are the overt aspects of culture which are easily visible, yet often hard to decipher. For example, organizational physical structures, rituals, dress, technology, arts, organizational charts are visible artifacts that reflect the values and express the way of life of the organization. In support, Goss (1988) opines that corporate building is invested with ideology, and the space within, around and between buildings is both produced and producing. (cited by Gibson, 2008). As such, they express deep patterns of organizational meaning and the organization's true personality. However, observers may not 
be able deduce meanings from these artifacts alone. The espoused beliefs and values are stated and explicitly articulated about what matter most in the organization as a guide to members' behavior. Nonetheless, the espoused values may also leave large area of behavior unexplained. Consequently, to fully appreciate the artifacts and how they are related to the values, there's a need to probe into the basic underlying assumptions that may be operating. These are the deep-rooted beliefs that are so much ingrained in organizational members which in turn dictates how they behave. Such assumptions are so entrenched and very difficult to change. According to Schein (2010), it is in this state that culture has its ultimate power- "after we have developed an integrated set of such assumptions ... we will be maximally comfortable with others who share the same set of assumptions and very uncomfortable and vulnerable in situations where different assumptions operate (p. 29). Culture at this level provides its members with a basic sense of identity and behavior which is the key to competitive advantage.

Organizational culture is noted to influence employees' decisions, choices and their relationship with others (Maseko, 2017; Arifin, 2015; KMPG, 2017). Culture determines how well employees' talents are put to use and managed. According to Taurisa and Ratnawati (2012), organizational culture set the rules for firm regulation, communication and command channel. Another important aspect of culture is that it acts as a kind of silent language that people respond to instinctively (Groysberg, Lee, Price and Cheng, 2018). Through it elusive and intangible nature, organizational culture exerts powerful influence on employees not necessarily with words but promoting them to the same direction. Corporate culture has been noted by Maseko (2017) to be differentiated on the basis its relative strength. A strong culture is one in which organizational members understand and believe in the goals, priorities and practices of the organization and act in ways consistent with the culture. In contrast, weak culture has employees relying on personal principles of norms and values in that the culture is not clearly defined, communicated and commonly accepted.

\section{The Influence of Organizational Structure}

The organizational structure is the mechanism that defines the framework for the operations of an organization by way of how jobs are divided and coordinated. Cole (1995) defines organization structure as an intangible web of relationships between people, their shared purposes and the tasks they set themselves to achieve those purposes. Organizational structure has a significant impact on the performance of human capital. It impacts communication patterns between employees, coordination, authority and the degree of freedom employees have to innovate and try new things. Besides, organizational structure is noted to be a set of boundaries for the efficient performance of members; arrangement of duties for work; and shape competence and behavior of employees (Tran \& Tian, 2013). It shows the existence of an interrelated and integrated system of positions in a firm (Alisa and Senija, 2010) and the social interaction among organizational members. The organizational structure also demonstrates the way power and responsibility are allocated and how work procedure is designed in a firm (Teixeria, Koufteros, and Peng, 2012). In addition, it plays a key role in a company's capacity to identify the knowledge sources needed, acquiring new knowledge, integrating it into the organization and recognizing its absorptive capacity (Martínez-León \& Martínez-García, 2011).

Bernstein and Nohria (2016) remark that organizational structure serves four key coordinating functions. Thus, organizational structure enables organizational members to draw on a wide variety of skills according to a division of labor that enhances human capital performance. More so, members of the organization are able to coordinate their activities and performance through hierarchical supervision, procedures and formal rules. Through the same 
structure, decision-making authority for organizational goals and priorities are established. Accordingly, boundaries are set for employees within the confines of the organizational structure. This also allows employees to develop important specific skills and capabilities as they bond and engage in interdependent work within the structure. Historically noted by Walton (1986), organizational structure is tied to effectiveness and a basis of organizing from hierarchical level to span of responsibility, role and position and a way of integration and problem-solving. This is confirmed by Zaki, Hussien, Sanad, and El-Khoriby (2015) who portray organizational structure as a pyramid having at the top the formal relationship of responsibilities and duties; superior and subordinates relationship; departmental activities allocated to workers; management of tasks and activities; and evaluation of employees based on stated procedures, policies methods and standards.

The features of organizational structure hinge on chain of command, work specialization, a span of control, departmentalization, decentralization and centralization (Goic, 2013). Work specialization is the degree to which task are grouped for efficiency. Departmentalization shows the basis at which works are grouped either by function or product. The chain of command and span of control depict the line of authority and the level of reporting and the number of employees under a manager. Centralization looks at the level of decision making from a single point of formal authority while decentralization gives decision-making with lower employees. Formalization of jobs by standardizing through rules, procedures and job descriptions.

Based on the elements or characteristics comes two main types of organizational structure which are mechanistic structure and organic or flat structure (Oshita, Pavao \& Borges, 2017). In the submission of Hunter (2015), Rozman and Kovac (2015), the mechanistic organizational structure portrays a narrow span of control, highly centralized, specialized and formalized. It is rigidly departmentalized and the chain of command is clearly defined. The organic or flat organizational structure is known to have a wide span of control, decentralized with low specialization and formalization and loose departmentation. The chain of command is complex. Mechanistic organization structure has its merits and demerits. According to Chimoriya (2017) the advantages are promotion of discipline among members, minimization of supervision cost, quick decision and implementation, network positions, fixation of responsibilities and effective management whereas the disadvantage is noted to be work overload on managers, autocratic leadership, static and rigidity of control, more formalization, impractical decision, one-way communication, coordination difficulties and focus on authority. Conversely, the merits of the organic organizational structure include decentralization of authority, free flow of information, feeling of team work, wide span of control, adaption in dynamic environment, relief to manager and increase efficiency. The disadvantages include the lack of coordination, complexity of decision, high administrative cost, problem of joint specialization, unpredictable working process and difficulty in control.

\section{Organizational Culture and Structure Convergence}

Organizational culture and structure are two sides of the same coin. Both are established and used by organizations to direct and shape the behaviors of employees toward the achievement of organizational goals. Hence, the key to maximizing human capital for optimum performance is the effectiveness of the organization at creating an effective culture and structure. Though organizational culture is mostly invisible and intangible, through the tangible organizational structure the organizational culture is made visible (Zaki, Hussien, Sanad \& El-Khoriby, 2015). Janicijevic (2013) remarks that organizational structure and culture impact each other and are mutually interdependent. Thus, organizational culture is the frame of reference whereas the 
organizational structure is the design. In the long run, organizational structure affects organizational culture by consolidating the culture through the mode of performing the tasks. Occasionally, employees have resigned from an organization because of poor or lack career and succession planning. Organizations with well-defined structure and a culture of promoting within have great chance of retaining valuable human capital. According to Umer and Naseem (2011), career development is an essential feature for human capital retention.

In more specific terms, organization culture has a variety of functions within an organization. One such function is a culture that enhances human capital performance through enforcement of continuous learning, innovation, creativity, risk-taking, team building, etc. Given a strong organization culture, organization members will make decisions and act in ways that are consistent with the values embedded in that culture. In other words, a strong corporate culture that emphasize on continuous learning will enhance human capital through acquisition and sharing knowledge among employees and modifying behavior to exhibit a positive perception of competency development. According to Steiger, Hammon and Galib (2014), successful change in an organization is realized when organizational culture ensures knowledge management of the human capital through the organizational structure elements with effective communication. Essentially, organizational structure dictates the work to be done in an organization and how the work is distributed among members of the organization. When the organization's reporting relationships, authority and procedures are carefully aligned with one another, the structure facilitates effective use of the firm's human capital. Thus, organizational structure plays a key control function that can have a significant positive impact to the organization's human capital performance, with a subsequent effect on sustainable competitive advantage as well. When the organization is decentralized, management can depend on people to try innovative ideas, spot opportunities that can be a source of competitive advantage. Therefore, we posit the following propositions:

P1: Organizational culture has a significant positive relationship with human capital performance.

P2: Organizational structure has a significant positive relationship with human capital performance.

\section{Human Capital Performance and Sustainable Competitive Advantage}

Employees' knowledge and skills accumulated through experience is valuable but they are not an end in itself. It is a means to creating a resource that is valuable for gaining sustainable competitive advantage. Employees who are knowledgeable, skilled, experienced and committed and understand the organizational culture and structure will be an agent of positive change (Adetoso \& Oladejo, 2013). Consequently, continuously investing in human capital that improve employees' capabilities and desired competencies has the potential to yield positive outcomes that can create sustainable competitive advantage. People's capabilities are resourceful in the appropriate culture and structure. To bring out the best in people, they have to be managed well which requires creating the appropriate culture and structure through strategic leadership. Thus, as reflected in Figure 1, we propose our third proposition as follows:

P3: Human capital performance has a positive effect in creating a sustainable source of competitive advantage. 


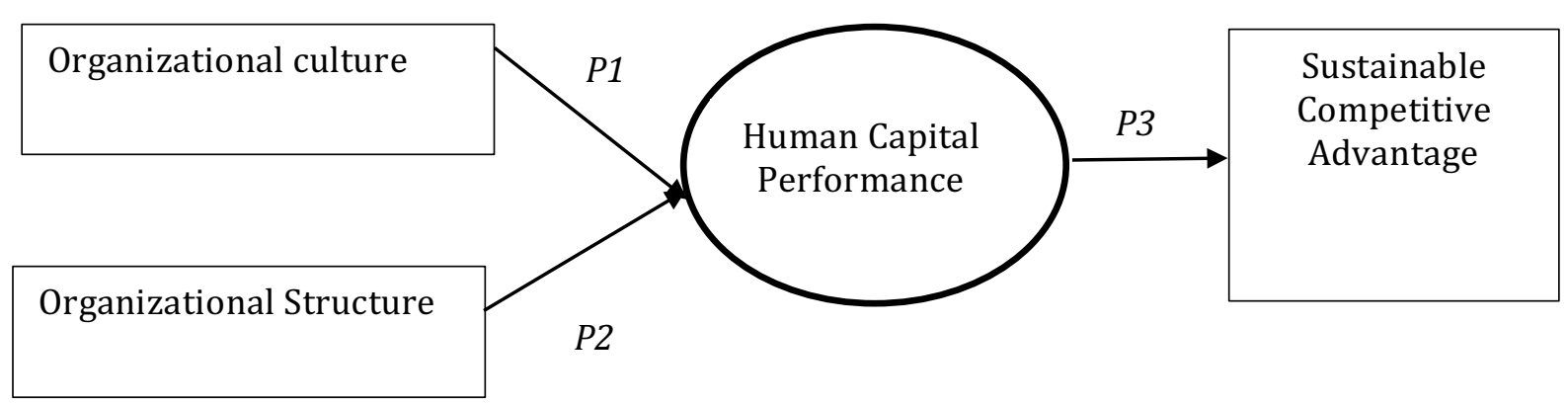

Figure 1: The Convergence of Organizational Culture, Organizational Structure and Human Capital

Source: Authors' compilation

Figure 1 suggests that high performing organizations obtain sustained competitive advantage by exploiting the strength of strong and effective organizational culture and structure to enhance capital performance.

\section{CONCLUSION}

In the $21^{\text {st }}$ century competitive environment, one key factor that will segregate winners from losers are organizations' ability to capitalize and maximize the full value of their human capital to their advantage. Organizations can no longer rely on low cost production to gain sustainable competitive advantage. Remarkably, organizations per se "do not work, people do" (Bernstein \& Nohria, 2016, p. 2). Hence, the importance of human capital cannot be over emphasized. Human capital resources are valuable sources of sustainable competitive advantage for all types of organizations because they are rare and cannot not be easily imitated or substituted. It is therefore very important for organizations to explore ways and means to boost the value of their human capital for optimum performance. Organizational culture and structure are essential tools that organizations can employ to shape organizational members towards the achievement of sustainable organizational performance.

Organizational culture gives employees some sense of direction by guiding the working relationships towards organizational goals and harnessing particular values such as adaptability, teamwork, continuous learning, innovation and mutual trust. Deliberately crafted, it can boost employees' commitment to the core purpose of the organization, it goals and the means used to accomplish goals. Similarly, organizational structure facilitates resource allocation to achieve organizational goals, enabling coordination and integration among departments necessary to maximize the potential of the organization's human capital to create a sense of common purpose. Thus, the two mechanisms are like the two sides of the same coin - they augment one another. Taken together, organizational culture and structure are important enablers of desired behaviors that can enhance human capital who is the employee with knowledge, skills, and experience. Therefore, organizational artifacts, values, assumptions, walls, departments, reporting systems are to be designed to exert a positive impact on human capital. The propositions posited in this paper provide for possible future empirical examination of the relationships and impact.

\section{References}

Adekola, A. (2014). Public investment in human capital and economic growth in Nigeria: analysis on regime shift. Journal of economics and Development Studies,2(2),213-231.

Adetoso, J. \& Oladejo, K.S. (2013). Management of human capital change, its implications for business growth and survival in Nigeria. International Journal for Business and Social Science, 4(10), 231-235. 
Adewale, 0.0. \& Anthonia, A.A. (2013). Impact of organizational culture on human resource practices: a case study of selected private universities. Journal of Competitiveness, 5(4), 115-133. DOI:10.7441/joe.2013.04.07

Agbanbegyan, A.G. (2017). Investments in fixed assets and human capital: two interconnected drivers of socioeconomic growth. Studies on Russian Economic Development, 28(4), 361-363.

Alika, I. \& Aibieyi, S. (2014). Human capital: definitions, approaches and management dynamics. Journal of Business Administrations and Education, 5(1), 55-78.

Alisa, D. \& Senija, N. (2010). The organizational structure and organizational culture interdependence analysis with special reference to Bosnian and Herzegovinian enterprise. The Organizational Structure EA, .43, 3-4.

Arifin, M. (2015). The influence of competence, motivation and organizational culture to high school teachers' job satisfaction and performance. International Education Studies, 8:38-44.

Armstrong, M. (2009). Armstrong's handbook of human resource management practice, 11th ed. London: Kogan Page

Barney J. \& Hesterly, W.S. (2006). Strategic Management and competitive advantage concepts. New Jersey: Pearson.

Barney, J.B. (1991). Firm resources and sustained competitive advantage, Journal of Management Studies, 17(1) pp. 99-120.

Baron, A. (2011). Measuring human capital, Strategic HR Review, 10 (2), pp.30-35, https:// doi.org/10.1108/14754391111108338

Bernstein, E. \& Nohria, N. (2016). Note on Organizational Structure. Harvard Business School Working Paper, No. 9-491-083.

Bontis, N., Dragonetti, N. C., Jacobsen, K., Roos, G. (1999) The knowledge toolbox: A review of the tools available to measure and manage intangible resources, European Management Journal, 17 (4), pp. 391-402.

Chimoriya, B. (2017). Advantage disadvantage of mechanistic organization and benefits. Retrieved from: http://www.wisenepali.com/2015/01/advantages-disadvantages-of-mechanistic.html

Colquitt, J. A., LePine, J. A., \& Wesson, M. J. (2013). Organizational behavior: Improving performance and commitment in the workplace (3rd ed). Burr Ridge, IL: McGraw-Hill Irwin.

Deal, T.E., \& Kennedy, A.A. (1982). Corporate cultures: the rites and rituals of corporate life. Reading, Mass: Addison-Wesley Publication Company.

Fisher, I. (1897). Senses of capital. The Economic Journal, 7, 199-213.

Flamholtz, E. G. (1996). The role of organizational structure and culture control. Effective Management. Pp. 117126.

Garibaldi, P. (2006). Personnel economics in imperfect labor markets. Oxford, England: Oxford Press

Gibson, S. F. M., (2008). Buildings and Organizations: The Shaping and the Shaped. Health Environments Research \& Design (HERD) Journal, 1 (4), pp 20-31. https://doi.org/10.1177/193758670800100403

Goic, S. (2013). Organizational structure, organizational dynamics and organizational culture: a research from Croatian Enterprises. Knowledge Management and Innovation, pp.497-506

Goldin, C. (2014). Human capital. Retrieved from:

www.scholar.havard.edu/files/goldin.files/human_capital_handbook_of_cliometrics_0.pdf.

Goss, J. (1988). The built environment and social theory: Towards an architectural geography. Professional Geographer, 40(4), 392-403

Groysberg, B., Lee, J., Price, J. \& Cheng, J.Y. (2018). The Leaders Guide to Corporate Culture. Harvard Business Review, pp. 1-15.

Hakim, A. (2015). Effect of organizational culture, organizational commitment to performance: study in hospital of district south Konawe of southeast Sulawesi. The International Journal of Engineering and Sciences. 4(5), 33-41.

Handy, C. B. (1993). Understanding organizations. New York: Oxford University Press.

Hitt, M.A. (2002). The essence of strategic leadership: managing human and social capital. The Journal of Leadership and Organizational Studies, 9(1), 3-11. 
Hitt, M.A., Ireland, R.D., \& Hoskisson, R.E. (2015). Strategic Management: Competitiveness and Globalization, 11 th ed. UK:Cengage Learning.

Hofstede, G. (1991). Culture and organizations: Software of the mind. London/New York: McGrawHill.

Hunter, S.D. (2015). Combining theoretical perspective on organizational structure performance relationship. Journal of Organizational Design, 4(2), 24-37.

Janicijevic, N. (2013). The mutual impact of organizational culture and structure. Economic Annals, 58(198), 3560. DOI: 10.2298/ERA1398035J.

Jenkins, M., Ambrosini, V., \& Collier, N. (2016). Advanced strategic management: A multi-perspective Approach, $3^{\text {rd }}$ ed. London: Palgrave

Jeston, J. \& Neils, J. (2014). Business Process Management. London: Taylor and Francis

Kolomiiets, U. \& Petrushenko, Y. (2017). The human capital theory. Encouragement and criticism. Socio Economic Challenges, 1(1), 77-80.

KPMG International (2017). Driving Corporate Culture from the Top. Retrieved From:

https://home.kpmg.com/xx/en/home/insights/2017/03/driving-corporate-culture-from-the-top-globalboardroom-insights.html

Martínez-León, I.M., \& Martínez-García, J.A. (2011) The influence of organizational structure on organizational learning, International Journal of Manpower, 32 (5/6), pp. 537-566, https://

doi.org/10.1108/01437721111158198

Maseko, T.S.B. (2017). Strong vs. weak organizational culture: Assessing the impact on employee motivation. Arabian Journal of Business and Management Review,7(1),1-5 DOI:10.4172/2223-5833.1000287

Mosley, R.W. (2007). Customer experience, organizational culture and the employer brand. Journal of Brand Management, 15(2), 123-134.

Newman, D. (2012). The People Centered Organization. Retrieved from: https://fowmedia.com/people-centeredorganization/

Nikpour, A. (2017). The impact of organizational culture on organizational performance: the mediating role of employee's organizational commitment. International Journal of Organizational Leadership, 6, 65-72.

O’Reilly, C.A., Chatman, J., \& Caldwell, D.F. (1991). People and organizational culture: A profile comparison approach to assessing person-organization fit. Academy of Management Journal, 34 (3), 487-516

OECD. (2001). Glossary of statistical terms. Retrieved from http://stats.oecd.org/glossary/detail.asp?ID=1264

Oshita, M.G.B., Pavao, J. A., \& Borges, I.M.T (2017). Analysis of the organization structure of enterprises of technological basis with project without incubators. International Journal of Innovation, 5(2), 211-221. DOI:10.5585/iji.v512.105

Owoyemi, 0.0. \& Ekwoaba, J. O. (2014). Organizational culture: A Tool for management to control, motivate and enhance employees' performance. America Journal for Business and Management, 3(3), 168-177. DOI: $10.11634 / 216796061403514$

Rozman, R., \& Kovac, J. (2015). Individual and organization creativity and innovation: their management. Dynamic Relationship Management Journal, 4(2)39-50. DOI:10.17708/DRMJ.2015.v04n02a03.

Rumelt, R. (1984). Toward a strategic theory of the firm, in R. Lamb (ed.) competitive strategic management. Englewood cliffs: Prentice-hall. 556-570

Scarborough, H. and Elias J. (2002). Evaluating human capital, CIPD, LONDON.

Schein, E.H. (2010). Organizational culture and leadership, $4^{\text {th }}$ ed. San Francisco: John Wiley \& Sons.

Scholz, C. (1987). Corporate Culture and Strategy - The Problem of Strategic Fit. Long Range Planning, 25, 3-16.

Schultz, T.W. (1961). Investment in human capital. The American Economics Review, 51 (1), 1-17.

Smith, A. (1776). An inquiry into the nature and causes of the wealth of nation, Book 2. Retrieved from: https://www.ibiblio.org/ml/libri/s/SmithA_WealthNations_p.pdf

Steiger, J. S., Hammou, K. A. \& Galib, M. H. (2014). An Examination of the Influence of Organizational Structure Types and Management Levels on Knowledge Management Practices in Organizations. International Journal of Business and Management, 9(6), pp. 43 - 57. 
Taurisa, C.M. \& Ratnawati, I. (2012). Analysis of the effect of organizational culture and organizational commitment on job satisfaction in improving the performance of employees. Journal forBusiness Education, 19, $170-178$.

Teixeria, R., Koufteros, X., \& Peng, X. D. (2012). Organizational structure, integration and manufacturing performance: a conceptual model and propositions. Journal of Operation and Supply Chain Management, 5(11).

Thompson, J., Scott, J.M., Martin F. (2014). Strategic Awareness and Change, $7^{\text {th }}$ ed. UK:Cengage Learning.

Tran, Q. \& Tian, Y. (2013). Organizational structure: influencing factors and impact on a firm. American Journal of Industrial and Business Management, 3,229-236. DOI:10.4236/ajibm.2012.32028

Trompenaars, A., \& Hampden-Turner, C. (1998). Riding the waves of culture: understanding cultural diversity in global business. New York: McGraw Hill.

Tumwine, S., Nasiima, S., \& kamukama, N. (2014). Human capital element and influence on performance: evidence from Uganda's Manufacturing Firms. Global Journal of Management and Business Research: Accounting and Auditing, 14(2).

Uden, A.V., Knoben, J. \& Verneulen, P. (2014). Human capital and innovation in developing countries: a frim level study. Working Paper. Institute of Management Research. Retrieved from: file:///C:/Users/MR\%20PEPRAH/Downloads/strat14-01totaal.pdf

Umer, M. \& Naseem, M.A. (2011). Employee retention (human capital) in business process outsourcing (BPO) industry in Pakistan. Global Journal for Management and Business Research, 11(3).

Walton, R.E. (1986). A vision-led approach to management restructuring. Organizational Dynamics, 14(4), 5-17.

Zaki, M. A., Hussien, H.S., Sanad, H.M. \& El-khoriby, S.S. (2015). Analyzing organizational structure for contracting firms of classification "A". Egypt Journal of Engineering Science, 43(3), 403-428. 